\title{
Doing Justice to the Environment
}

\author{
Julie Adshead*
}

\begin{abstract}
This article examines some of the characteristic features of environmental offences, in particular the ways in which these offences and their treatment in the courts deviate from general principles of criminal law. Despite the fact that environmental offences are often labelled as 'quasi-criminal', there has been long-standing criticism of penalties, particularly the low level of fines in magistrates' courts. The article also considers the possible reasons behind this and argues that, as well as the inexperience of lay magistrates, the perception of environmental crime, fuelled by the strict liability nature of most environmental offences, is a significant factor. The recent introduction of civil sanctions is evaluated along with recommendations for new sentencing powers and sentencing guidelines. The article concludes by considering further suggestions for more effective enforcement of environmental crime in the courts, including the introduction of specialist magistrates' courts and the use of more fault-based offences or a general defence of due diligence for environmental crimes.
\end{abstract}

Keywords Environmental crime; Strict liability; Causation; Magistrates' courts; Sentencing

Environmental offences, along with other regulatory offences, are commonly referred to as not truly criminal in nature. ${ }^{1}$ The perceived lack of moral blameworthiness for regulatory offences is a significant justification for the imposition of strict liability. Due perhaps to the fact that culpability is not such an issue with environmental offences, the courts have also taken a different approach to causation than normal in criminal law. ${ }^{2}$ However, the focus of environmental law has changed significantly over recent times. Whereas initially environmental regulation was primarily concerned with the threat to public health, the protection of the environment is now recognised as important to the survival of mankind. Accompanying this change in focus comes recognition that serious breaches of environmental regulation should be met with appropriately robust sanctions and carry the stigma of criminal conviction. However, despite high potential penalties, the courts have come under criticism for the low level of fines imposed, which, it is argued, do not reflect the cost of non-compliance and do not act as a deterrent. ${ }^{3}$

* Senior Lecturer in Law, University of Salford; e-mail: j.d.adshead@salford.ac.uk.

1 Sherras v De Rutzen [1895] 1 QB 918 at 922; A. P. Simester, G. R. Sullivan, J. R. Spencer and G. Virgo, Simester and Sullivan's Criminal Law: Theory and Doctrine, 4th edn (Hart: Oxford, 2010); K. Hawkins, Environment and Enforcement; Regulation and the Social Definition of Pollution (Clarendon Press: Oxford, 1984); M. Grekos, 'Environmental Fines-All Small Change' [2004] JPL 1330.

2 Alphacell Ltd v Woodward [1972] AC 824; Environment Agency v Empress Car Co. (Abertillery) Ltd [1999] 2 AC 22.

3 C. Dupont and P. Zakkour, Trends in Environmental Sentencing in England and Wales, A Report by Environmental Resources Management Ltd for DEFRA, November 2003; C. Hatton, P. Castle and M. Day, 'The Environment and the Law-Does our Legal System Deliver Access to Justice? A Review' (2004) 6 Env Law R 240.

The Journal of Criminal Law (2013) 77 JCL 215-230 


\section{Features of environmental offences}

The general water pollution offence provides a good example of a typical strict liability environmental provision. It is an offence under reg. 38 of the Environmental Permitting (England and Wales) Regulations 2010 (SI 2010 No. 675) to contravene reg. 12(1), which states:

A person must not, except under and to the extent authorised by an environmental permit-

(a) ...

(b) cause or knowingly permit a water discharge activity or groundwater activity.

There are two separate offences here, but because of the ease of prosecuting the 'causing' offence, the 'knowingly permitting' offence is rarely pursued. The only relevant consideration for the court in the former offence is whether the defendant has caused the entry of the polluting matter into the water course. ${ }^{4}$ Similarly worded offences are to be found in, for example, waste management provisions. ${ }^{5}$

The decision in the case of $R \mathrm{v}$ Dovermoss $L t^{6}$ clearly demonstrates that the thrust of the general water pollution offence ${ }^{7}$ is not, in fact, upon pollution, but upon entry of potentially polluting matter. A water supply was contaminated by ammonia from animal slurry on a nearby field. The defence argued that the receiving waters had not suffered any harm and ammonia levels in the water supply did not exceed maximum concentrations permitted under drinking water regulations. The court held that it was not necessary for the prosecution to prove that the substance had actually caused harm, it was sufficient that there was a likelihood or capability of causing harm to animal or plant life or those who use water.

Defences to environmental offences tend to be limited and narrowly interpreted. Again, using the general water pollution offence as an example, there is a defence for acting under an environmental permit in reg. 12(1) and there are defences in reg. 40 of EPR 2010 for discharges from abandoned mines ${ }^{8}$ and emergency. ${ }^{9}$ The defence of emergency is subject to a requirement to minimise harm and report to the regulator within a reasonable time period. ${ }^{10}$ This defence has been narrowly interpreted by the courts and it can be seen from the case of Express Ltd $\mathrm{v}$ Environment Agency ${ }^{11}$ (one of the rare cases when the defence was successfully raised) that the element of emergency is not of primary concern to the court, but rather that the action is done to avoid danger

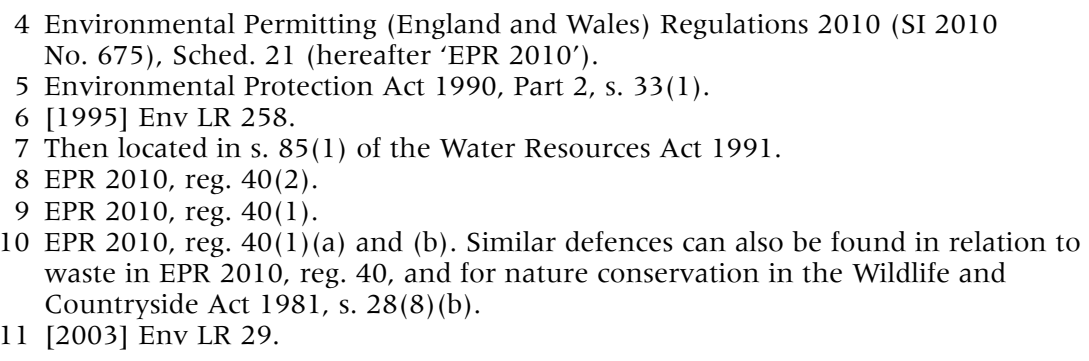


to human life or health. This is now reflected in the wording of reg. 40 .

\section{Strict liability}

The strict liability nature of most environmental offences is worthy of further consideration. These are amongst a body of regulatory offences, ${ }^{12}$ which, from the late part of the 19 th century onwards, were viewed by the courts as not requiring mens rea. There are a number of reasons advanced for this departure from 'the foundation of all criminal justice $^{\prime 13}$. At the root of it seems to be the lack of stigma accorded to conviction of these types of offence. Like other 'technical' ${ }^{14}$ offences, environmental crimes have been viewed by the courts as 'quasicriminal' or malum prohibitum offences. ${ }^{15}$ Such offences have been famously described as 'a class of acts ... which are not criminal in any real sense, but are acts which in the public interest are prohibited by penalty'. ${ }^{16}$ This is in contrast to the 'truly criminal' or 'serious' malum in se offences, such as homicide, where the presumption that mens rea is required remains, based on the blameworthiness of the perpetrator in such cases. ${ }^{17}$ The public interest element of strict liability offences is another justification. ${ }^{18}$ These are offences designed to protect the public good, initially public health and safety and, more latterly, environmental protection, and the need to protect the public justifies conviction without fault. It is also argued that those who embark on inherently dangerous activities should accept the potential of criminal responsibility. ${ }^{19}$ Defendants are, more often than not, corporations and hence the personal stigma of conviction is arguably not so significant. ${ }^{20}$ Also, it is suggested that companies are in the best position to be able to prevent and control regulatory wrongdoing. ${ }^{21}$

Padfield summarised the advantages of strict liability offences for regulatory crime as being certainty, efficiency and effectiveness. ${ }^{22}$ Indeed, one acknowledged reason for the imposition of strict liability lies in the difficulty for the prosecution of establishing mens rea and the practical economic problems of so doing. ${ }^{23}$ Prosecution is simplified and

12 For example, early factory legislation dealing with industrial safety.

$13 R$ v Sleep [1861] 8 Cox CC 472 at 477, per Cockburn CJ.

14 Also referred to as 'public welfare' or 'regulatory' offences.

15 Pearks, Gunston $\theta$ Tee Ltd v Ward [1902] 2 KB 1 at 11; London Borough of Harrow v Shah [1999] 3 All ER 302; Sweet v Parsley [1970] AC 132 at 149 and 163; Alphacell Ltd v Woodward [1972] AC 824 at 839 and 848; Simister et al., above n. 1.

D. J. Baker, Glanville Williams Textbook of Criminal Law (Sweet \& Maxwell: London, 2012) 1280.

16 Sherras v De Rutzen [1895] 1 QB 918 at 922.

17 Gammon Ltd v Attorney-General of Hong Kong [1985] 1 AC 1 at 14, Privy Council; A. Simester, Appraising Strict Liability (Oxford University Press: Oxford, 2005).

18 Ibid.

19 J. G. Murphy and J. L. Coleman, Philosophy of Law (Routledge: 1990) 128.

20 Simester et al., above n. 1; Simester, above n. 17.

21 Ibid.

22 N. Padfield, 'Clean Water and Muddy Causation: Is Causation a Question of Law or Fact, or Just a Way of Allocating Blame?' [1995] Crim LR 683; see also Simester, above n. 17.

23 As, e.g., with speeding offences. 
evidential problems allayed, of particular importance when defendants are large corporations. ${ }^{24}$ Strict liability, it is argued, is an effective compliance tool in the hands of the enforcing body. It acts as a deterrent, causing operators in high-risk activities to exercise more caution and thus prevents incidents, ${ }^{25}$ and it can also be a powerful weapon in compliance negotiations.

There is a counter-argument that strict liability hinders optimum enforcement. An alternative view is that when operators find themselves liable for accidental occurrences, they are discouraged from innovation and careful operation of their facilities. The level of precautions to be taken is unknown and, therefore, it is suggested, the minimum possible preventative measures will be adopted by operators. ${ }^{26}$ Prosecution and fines can become business expenses ${ }^{27}$ and ultimately, it is suggested that a strict liability regime will lead to grievance on the part of the regulated and a loss of confidence in the system of control. Some suggest that this is too high a price to pay for efficiency. ${ }^{28}$

As noted above, one of the main justifications for regulatory offences being of strict liability is the lack of stigma involved on conviction. However, as also observed earlier, environmental crimes arguably attract more stigma in these times of enhanced environmental awareness. Certainly, sentences of up to 12 months' imprisonment upon conviction in the magistrates' courts and up to five years in the Crown Court suggest that there is a high level of moral reprehension attached to environmental crime. Some argue that the use of strict liability in stigmatic crimes, which may lead to the conviction of the morally innocent, is unjustified, whereas it may be legitimate in non-stigmatic offences such as quasi-criminal regulation. It is suggested that the instrumental arguments for strict liability in regulatory crime, rehearsed above, are 'trumped' if crimes are stigmatic. ${ }^{29}$

A third and alternative route has been proposed and this involves the introduction of negligence as an element of regulatory offences. ${ }^{30}$ The enforcing body considers negligence and blame in deciding whether to prosecute $^{31}$ and, as will be explored further below, the strict liability nature of the offences and blameworthiness of defendants can be factors in the determination of sentence. Thus, it is argued that negligence should also be considered by the courts in determining guilt. ${ }^{32}$ In the light of the introduction of civil sanctions for some environmental offences and the serious nature of those that come before the courts,

24 Simester et al., above n. 1.

25 Ibid.; Simester, above n. 17.

26 Simester, above n. 17.

27 Baker, above n. 15 at 1274

28 Ibid. at 1269.

29 Simester, above n. 17.

30 Ibid.

31 N. Stanley, 'The Empress Decision and Causing Water Pollution: A New Approach to s. 85(1) of the Water Resources Act 1991 Strict Liability' (1999) Water Law 41.

32 Baker, above n. 15 at 1273. 
there are, perhaps, arguments for revisiting the strict liability nature of such offences and these will be returned to in the conclusions and recommendations of this article.

\section{Causation}

The courts have also taken a different approach to causation in cases of environmental pollution. The traditional two-stage approach requires first the consideration of 'factual causation' by means of the application of the 'but for' test. The result may, however, be unsatisfactory and lead to the conviction of the morally innocent. ${ }^{33}$ Indeed, it is suggested that this first test is not a variety of causation at all, but merely an 'indicum of causal relationships, a convenient proxy'.$^{34}$ The courts then proceed to consider 'legal causation'. The additional test was developed because of the reluctance to convict, particularly of homicide, those who are not blameworthy. ${ }^{35}$ Glanville Williams considers this second step not to be a test of causation either, but a moral reaction and prefers reference to imputability, responsibility or blameworthiness. ${ }^{36}$ Others acknowledge that legal causation represents a value judgement, ${ }^{37}$ which takes account of policy and the social context of the time. ${ }^{38}$ In legal causation, the requirement is for there to be a culpable act, which must have caused the result; this must be more than a minimal cause and there must be no novus actus interveniens that breaks the chain of causation. ${ }^{39}$ The need for 'outcome responsibility' is central to legal causation. ${ }^{40}$ This is the 'cardinal principle that a person is primarily responsible only for what he himself does or incites', ${ }^{41}$ which was well illustrated in the case of $R \mathrm{v}$ Kennedy (No. 2). ${ }^{42}$

In cases of pollution, it is argued that a different value judgement is involved. The purpose here is to make the polluter pay and not to allocate blame. ${ }^{43}$ Perhaps as a reflection of this, the courts have deviated from the central principle of outcome responsibility and have taken a different approach to omissions as well as to intervening acts. This can be recognised in the landmark water pollution case of Alphacell Ltd $\mathrm{v}$ Woodward. ${ }^{44}$ Alphacell Ltd manufactured paper at a riverside site. The water used to wash the raw materials was stored in tanks with a pump

33 Padfield, above n. 22 at 684.

34 A. P. Simester and G. R. Sullivan, 'Being There' [2012] 71 Camb LJ 29.

35 Padfield, above n. 22 at 683.

36 Baker, above n. 15 at 199.

37 Padfield, above n. 22 at 685 .

38 A. Norrie, 'A Critique of Criminal Causation' (1999) 54 MLR 701.

39 Padfield, above n. 22 at 684-5.

40 P. Cane and J. Gardner (eds), Relating to Responsibility: Essays in Honour of Tony Honoré (Hart: Oxford, 2001).

41 Baker, above n. 15 at 217; R v Tilley (2009) 173 JP 393.

42 [2007] UKHL 38, [2008] 1 AC 269.

43 Padfield, above n. 22 at 686.

44 [1972] AC 824. 
that automatically switched on when the water reached a predetermined level, thus preventing overflow from the tanks into the river. The tanks and pump were regularly inspected. but nonetheless the pump failed to operate on one occasion due to obstruction by vegetation, and polluting effluent flowed into the river. The company was not aware of the entry of the effluent into the watercourse. It appealed against its conviction to the House of Lords on the basis that the offence required some element of recklessness, negligence or intention, which was absent. In dismissing the appeal, as well as affirming the strict liability nature of the offence, their Lordships concluded that 'causing' was to be determined by looking at the facts alongside the ordinary meaning of the word 'cause'. Despite Lord Wilberforce seeking 'proper attribution of responsibility', ${ }^{45}$ this clearly differs from the principle of 'outcome responsibility' alluded to above.

A number of cases followed where the courts moved away slightly from the approach taken in Alphacell, in finding defendants, who had been passive, not guilty of the general water pollution offence. ${ }^{46}$ The Alphacell position was reaffirmed in the controversial case of Environment Agency v Empress Car Co. (Abertillery) Ltd. ${ }^{47}$ Empress, a car sales company, stored red diesel in a tank on their premises. There was a protective bund surrounding the tank, but this had been overridden by the company. An unknown person entered the premises and opened the tap on the tank allowing its entire contents to flow through a storm drain into a nearby watercourse. On appeal, counsel for the appellant company argued that there had been no positive act, which amounted to 'causing' the entry as it had, in fact, been the act of a stranger. Dismissing the appeal, the House of Lords made clear that 'causing', for the purposes of the general water pollution offence, could take place with or without the occurrence of other facts, which produced a situation in which the polluting matter could escape. The question was whether this was an ordinary fact of life or something extraordinary and this was one to which the courts had to apply common sense and knowledge of what happens in the area. This returns us to the position of Alphacell and the requirement merely for an 'active operation'. In effect liability in water pollution cases can arise for omissions and also the normal approach in criminal law, whereby a voluntary human act amounts to a novus actus interveniens, can be set aside.

The decision in Empress has been widely criticised. Lord Hoffmann's judgment ${ }^{48}$ proposes that there are in fact no general principles of causation, thus making the matter just one of statutory interpretation. Critics suggest that this jeopardises any stable doctrine of causation as

45 Above n. 44 at 835.

46 Price v Cromack [1975] 1 WLR 988; Wychavon District Council v National Rivers Authority [1993] I WLR 125; National Rivers Authority v Welsh Development Agency [1993] Env LR 407.

47 [1999] 2 AC 22.

48 Ibid. at 29 et seq.; cited in $R$ v Williams [2010] EWCA Crim 2552. 
different causal responsibilities will apply to different crimes. ${ }^{49}$ Simester et al. assert that the leading judgment of Lord Hoffmann is 'profoundly unsatisfactory's0 and wrong in principle having 'trampled upon a fundamental precept of criminal law $^{\prime 51}$ (that an individual is responsible for his or her own autonomous actions and not for those of others). Nonetheless, it seems, for the moment, and for water pollution offences at least, ${ }^{52}$ that a deviation exists from some of the generally accepted principles of criminal law. The approach taken to causation in pollution cases, coupled with the strict liability nature of the offences, may well be influential in sentencing patterns in the lower courts.

\section{Environmental crime in the courts}

Most environmental prosecutions are brought by the Environment Agency in the magistrates' courts. The number of environmental prosecutions has always been low and (as can be seen in Table 1 below) actually fell quite significantly in the period from 2005-2010.

Table 1. Statistics from National Enforcement Database

\begin{tabular}{ll}
\hline Year & Prosecutions \\
\hline 2005 & 887 \\
2006 & 744 \\
2007 & 808 \\
2008 & 722 \\
2009 & 671 \\
2010 & 653 \\
2011 & 694 \\
\hline
\end{tabular}

Prior to the formation of the Environment Agency in 1996, the low number of prosecutions was explained by the informal regulatory style, adopted by the individual agencies that preceded its establishment. ${ }^{53}$ The Environment Agency also adopts a compliance approach, but alongside this has displayed a greater willingness to bring certain offenders to court. There was a rise in the number of prosecutions brought and a year on year increase immediately following the establishment of the Agency. ${ }^{54}$ Nonetheless the number of prosecutions remains relatively

49 G. R. Sullivan and A. P. Simester, 'Causation Without Limits: Causing Death While Driving Without a Licence, While Disqualified, or Without Insurance' [2012] Crim LR 753.

50 Simester et al., above n. 1 .

51 Ibid.

52 See also the offence of causing death by driving when unlicensed, disqualified or uninsured: Sullivan and Simester, above n. 49; $R$ v Williams [2011] Crim LR 468 at 471-2, commentary by D. Ormerod.

53 Hawkins, above n. 1; D. Vogel, National Styles of Regulation (Cambridge University Press: Cambridge, 1986).

54 Dupont and Zakkour, above n. 3. 
small as illustrated by recent statistics from the Environment Agency on water pollution incidents and prosecutions in Table 2 below.

Table 2. Water quality incidents and prosecutions, National Enforcement Database

\begin{tabular}{lll}
\hline Year & Incidents & Prosecutions \\
\hline 2010 & 9285 & 125 \\
2011 & 9176 & 120 \\
\hline
\end{tabular}

\section{Enforcement in the magistrates' courts}

For most environmental offences, there is an upper limit of fine in the magistrates' courts of $£ 50,000$ along with the option of imprisonment for a period of up to 12 months. Fines in the Crown Court are unlimited and magistrates are encouraged to refer to the Crown Court for sentencing where their sentencing powers are insufficient. ${ }^{55}$ There have been a number of studies of the sentencing patterns of magistrate's courts over the years, all of which present the same picture of fairly low levels of average fines. ${ }^{56}$ Figures from the Environment Agency show an average fine for organisations across all courts (magistrates' courts and Crown Court) in England and Wales of around $£ 8,000$ and the Agency notes that there has been in the region of a 5 per cent increase in these average fine levels annually. ${ }^{57}$ Custodial sentences are extremely rare. ${ }^{58}$

There has been long-standing criticism of the level of penalties in the magistrates' courts for environmental offences and there is a considerable body of opinion that regards fines as being too low. ${ }^{59}$ The Environment Agency has consistently voiced its frustration at the level of fines imposed $^{60}$ and, in the majority of cases, the financial penalties do not

55 Sentencing Council, Magistrates' Court Sentencing Guidelines (2008) as updated, available at http://sentencingcouncil.judiciary.gov.uk/guidelines/guidelines-to-

download.htm, accessed 16 April 2013; Magistrates' Association, P. Stookes (ed.), Costing the Earth: Guidance for Sentencers, October 2003.

56 For example, Dupont and Zakkour, above n. 3.

57 D. Stott, 'Environmental Enforcement in the UK' (2009) 11 Journal of Environmental Monitoring 470-4.

58 Dupont and Zakkour, above n. 3; C. Hatton, P. Castle and M. Day, 'The Environment and the Law-Does our Legal System Deliver Access to Justice? A Review' (2004) 6 Env L Rev 240.

59 See, e.g., House of Commons Environmental Audit Committee, 'Environmental Crime and the Courts: Sixth Report of Session 2003-04', HC 126, May 2004 10; P. Hampton, 'Reducing Administrative Burdens: Effective Inspection and Enforcement', March 2005, HM Treasury; Dupont and Zakour, above n. 3; Hatton et al., above n. 58 .

60 See, e.g., Environment Agency, 'Spotlight on Business, Environmental Performance in 2005: The Environment What's In It for You?', July 2006. 
reflect the economic benefit derived from non-compliance and consequently do not act as a deterrent. ${ }^{61}$ There are a number of explanations advanced as to why the level of fines in the magistrates' courts is low. The traditional explanation centres on the inexperience of magistrates' courts with environmental offences. The argument is that a vicious circle occurs whereby most offences are not prosecuted; magistrates, therefore, gain little experience and deliver lenient sentences ${ }^{62}$. The low sentences, in turn, discourage the regulatory body from bringing prosecutions. ${ }^{63}$ Watson suggests that: 'If prosecutions became more common magistrates would be better equipped to treat environmental offences as serious crimes. ${ }^{64}$ There is some irony in the argument that the low level of fines for environmental offences, so frequently criticised by the Environment Agency, is, in fact, caused by the reluctance of the regulatory body to prosecute. Those who suggest that the Agency is applying 'the realistic prospect of conviction' test too rigidly look to the Agency's 95 per cent success rate in prosecutions to support their argument. ${ }^{65}$ The Environment Agency, on the other hand, denies any reluctance to bring prosecutions and maintains that it is concentrating resources on behaviour that represents the greatest risk to the environment. ${ }^{66}$ It should, however, be noted that the strict liability nature of most environmental offences (discussed above) is, no doubt, instrumental in the high percentage rate of successful prosecutions.

There is no doubt that, amongst their routine business, lay magistrates encounter barely any cases of environmental crime. Environmental cases can also be extremely complex and technical, often involving evidential material on industrial processes, pollutants and pathways, ${ }^{67}$ which, together with their unfamiliarity, must surely cause problems for magistrates. Magistrates do, of course, benefit from the assistance of their legal advisers and have some degree of guidance. ${ }^{68}$ However, unlike other criminal offences, there are, as yet, no published tariff guidelines for environmental offences. Despite the recommendation of the Sentencing Advisory Panel, in 2000, ${ }^{69}$ the Court of Appeal declined to issue tariff guidelines. ${ }^{70}$ There have been recommendations

61 House of Commons Environmental Audit Committee, above n. 59; Hampton, above n. 59.

62 Dupont and Zakkour, above n. 3; T. Moran, 'Magistrates' Courts and Environmental Regulators-Attitudes and Opportunities' (2005) 4 Journal of Environmental Health Research 25.

63 Dupont and Zakkour, above n. 3; Moran, above n. 62; M. Watson, 'Low Fines for Environmental Offences? Blame the Regulators Not the Courts' (2003) 167 JP 50.

64 Watson, above n. 63.

65 Ibid.; Moran, above n. 62.

66 D. Stott, 'Low Fines for Environmental Blame the Regulators Not the Courts' (2003) 167 JP 235 (in response to Watson, above n. 63).

67 N. Parpworth, 'Section 34(1)(b) of the Environmental Protection Act 1990: The Scope of the Offence' (2007) 171 JP 33.

68 Sentencing Council, above n. 55.

69 Sentencing Advisory Panel, M. Wasik (Chair), 'Environmental Offences: The Panel's Advice to the Court of Appeal', March 2000, 1.

70 The opportunity arose in Environment Agency v Milford Haven Port Authority (The Sea Empress) [2000] 2 Cr App R (S) 423. 
to the Sentencing Guidelines Council over the years to publish guidelines for all cases of regulatory non- compliance ${ }^{71}$ and academic commentators have echoed the call. ${ }^{72}$ The Sentencing Council has commenced work on a draft guideline for environmental offences and an environmental offences guideline consultation is running from March 2013 to June 2013, so this is one area where it is hoped further assistance will soon be available to the lower courts.

The factors alluded to above have led commentators to doubt the suitability of the criminal courts as a venue for dealing with environmental cases and over the years there have been repeated calls for matters relating to environmental law to be dealt with in a 'stand-alone' environmental court. This proposition has, in the past, been supported by key members of the judiciary ${ }^{73}$ and proponents of an environmental court have looked to the Land and Environment Court of New South Wales as an operational example. There have, however, been mixed views as to the success of the New South Wales project and its potential for application in this country. ${ }^{74}$ Support for the idea of an environmental court reached its peak early this century and there is now less enthusiasm for the notion. ${ }^{75}$

There have also been arguments in favour of a new environmental tribunal to handle regulatory appeals under environmental legislation. ${ }^{76}$ Fresh momentum for this latter proposal flows from the creation of the First-tier Tribunal (Environment) set up to deal with appeals against civil sanctions deriving from Part 3 of the Regulatory Enforcement and Sanctions Act 2008. Another suggestion advanced to tackle the problem of under-enforcement in the magistrates' courts is the creation of specially designated courts, within the existing court system. Alternatively, either district judges or lay magistrates specifically trained to hear environmental cases could be employed within the existing magistrates' court framework. ${ }^{77}$ These ideas formed part of the recommendations of both the Environmental Audit Committee ${ }^{78}$ and the Environmental

71 R. Macrory, 'Regulatory Justice: Making Sanctions Effective, Final Report', Cabinet Office, November 2006.

72 See, e.g., N. Parpworth 'Environmental Offences: The Need for Sentencing Guidelines in the Crown Court' (2008) 1 Journal of Planning and Environment Law 18.

73 Lord Woolf, 'Are the Judiciary Environmentally Myopic?' (1992) 4 Journal of Environmental Law 12; R. Carnwath, 'Environmental Enforcement: The Need for a Specialist Court' [1992] JPL 799.

74 M. Day, R. Stein and W. Birtles, 'An Environmental Court-Part 2' (2001) 151 NLJ 697; P. Ryan, 'Court of Hope and False Expectation: Land and Environment Court 21 Years On' (2002) 13 Journal of Environmental Law 301; P. L. Stein, 'Specialist Environmental Courts: The Land and Environment Court of New South Wales, Australia' (2002) 4 Env L Rev 5.

75 Lord Justice Carnwarth, 'Judicial Protection of the Environment: At Home and Abroad' (2004) 16 Journal of Environmental Law 326.

76 R. Macrory, 'Consistency and Effectiveness: Strengthening the New Environment Tribunal', January 2011, Centre for Law and the Environment, University College London.

77 R. Malcolm, 'Prosecuting for Environmental Crime: Does Crime Pay?' (2002) 14 Environmental Law and Management 4.

78 House of Commons Environmental Audit Committee, above n. 59 at 10. 
Justice Project of $2004^{79}$ and are supported by the Environment Agency and some academic commentators. ${ }^{80}$ A similar model is adopted for health and safety prosecutions, which are brought to a single magistrates' court in a particular region.

\section{Perceptions of environmental crime}

There is another factor to consider when looking at sentencing patterns for environmental offences and this is the perception of environmental crime by the public, magistrates and higher courts. It has been noted above that strict liability offences are often viewed as 'quasi-criminal' and there is an argument that the public and lay magistrates look upon environmental crime, like white-collar crime, as not as morally culpable as criminal activities such as assault or burglary. ${ }^{81}$ This perception perhaps ignores the development in environmental awareness over the past three or four decades. The emphasis in early environmental protection provisions was primarily upon the protection of public health from environmental pollution. This can be recognised in the judgments of the courts as, for example, in Alphacell when Lord Salmon reflected upon the consequences in terms of river water quality if water pollution offences went unpunished: 'As a result, many rivers which are now filthy would become filthier still and many rivers which are now clean would lose their cleanliness. ${ }^{82}$

However, the recognition in more recent years of an eco-system approach to environmental protection and the imperative of climate change have changed understanding of environmental damage from a potential threat to individual human health to a threat to the survival of the human race. As Sedley LJ has stated:

... environmental crime, if established, strikes not only at a locality and its population, but in some measure too at the planet and its future. Nobody should be allowed to doubt its seriousness. ${ }^{83}$

This recognition of the seriousness of environmental damage is reflected in the high upper limits for fine and sentence in the courts. ${ }^{84}$ It seems likely, however, that lay magistrates and members of the judiciary who do not subscribe to the view that environmental crime is serious and continue to distinguish environmental offences from the activities of 'true criminality ${ }^{85}$ will not consider high penalties to be appropriate. ${ }^{86}$ The strict liability nature of the offences in itself, coupled with the novel approach to causation and accompanying arguments in mitigation from

79 Hatton et al., above n. 58.

80 P. De Prez, 'Excuses, Excuses: The Ritual Trivialisation of Environmental Prosecutions' (2000) 12 Journal of Environmental Law 65; Malcolm, above n. 77; J. Bates, 'Examining Water Pollution Law and Regulation in Light of Current Government and EU Policy' (1997), paper presented at Water Law Conference, London, February 1998.

81 Hawkins, above n. 1; Grekos, above n. 1.

82 [1972] AC 824.

83 Magistrates' Association, above n. 55, Foreword.

84 Hawkins, above n. 1; Grekos, above n. 1.

85 Malcolm, above n. 77.

86 Moran, above n. 62; De Prez, above n. 80. 
the defence, ${ }^{87}$ may also influence the courts in their sentencing. ${ }^{88}$ Indeed, this was acknowledged in the Court of Appeal in $R \mathrm{v}$ Yorkshire Water Services $L t d^{89}$ where fines of $£ 50,000$ and $£ 25,000$ were reduced to $£ 10,000$ and $£ 5,000$ respectively because the appellant's plea had been put forward and accepted on the basis of strict liability.

\section{Civil sanctions}

Prosecution is, of course, only one of a range of enforcement alternatives and the Environment Agency has long had other enforcement powers available. ${ }^{90}$ A suggestion raised by some critics of strict liability regulatory offences has been to make administrative penalties available for low-level regulatory crime. ${ }^{91}$ Two influential reviews in $2005^{92}$ and $2006^{93}$ eventually led to the provisions to be found in Part 3 of the Regulatory Enforcement and Sanctions Act 2008 creating civil sanctions for regulatory offences.

An Order was made in $2010^{94}$ applying the relevant section of the Regulatory Enforcement and Sanctions Act 2008 to a number of environmental offences and the Environment Agency started using civil sanctions in January 2011. The sanctions available include both fixed and variable monetary penalties as well as a range of new notices. ${ }^{95}$ The provisions also allow for enforcement undertakings to be agreed. These administrative sanctions are, at the moment, limited to a fairly small number of offences and, where applicable, not all of them are available. ${ }^{96}$ The Agency must be satisfied 'beyond reasonable doubt' that the person committed the offence in order to use the new powers. There is a right of appeal on specific grounds such as error of fact to the new Firsttier Tribunal (Environment), established pursuant to the Tribunals Courts and Enforcement Act 2007. Accompanying and aligned to the new powers is a new Environment Agency enforcement and prosecution policy, which aims to focus on both 'customer' and 'outcome'. ${ }^{97}$

The introduction of civil sanctions has not been without criticism" ${ }^{98}$ and the extension of sanctions to environmental permitting offences, originally due to have taken place in April 2011, has been delayed,

87 Above n. 86

88 Ibid.

89 [2002] Env LR 18.

90 For example, enforcement notices, suspension, revocation and variation of permits.

91 Padfield, above n. 22; Baker, above n. 15.

92 P. Hampton, 'Reducing Administrative Burdens: Effective Inspection and Enforcement', HM Treasury, March 2005.

93 Macrory, above n. 71.

94 Environmental Civil Sanctions (England) Order 2010 (SI 2010 No. 1157), in force on 6 April 2010.

95 Compliance notices, restoration notices and stop notices.

96 DEFRA, Guidance on the Application of Civil Sanctions, Annex 1.

97 Environment Agency, Enforcement and Sanctions Statement, Guidance and Offence Response Options, available at http://www.environment-agency.gov.uk/ business/regulation/31851.aspx, accessed 16 April 2013.

98 See, e.g., J. Black, 'Tensions in the Regulatory State' [2007] PL 67, J. Maurici, 'Rethinking Regulatory Sanctions-Regulatory Enforcement and Sanctions Act 2008-An Exchange of Letters' (2009) 21 Environmental Law and Management 183. 
pending a cross-government review. This followed representations by the Minister for Government Policy that the idea of regulators imposing sanctions directly without recourse to the courts was 'intolerable' and would lead to 'sloppy regulation'. ${ }^{99}$ Academics and practitioners have also raised concerns over the enforcing body making decisions on criminal offences and potentially significant penalties and the appropriateness of removing this element of the administration of justice from the courts. ${ }^{100}$ Another fear is that the employment of civil sanctions will reinforce the idea that environmental offences are less serious than traditional crime and herald the beginning of the decriminalisation of environmental offences. ${ }^{101}$

It should be noted, however, that similar powers have existed with regulators for many years, both in the environmental sphere ${ }^{102}$ and other areas of UK regulatory law. ${ }^{103}$ Overseas jurisdictions also utilise administrative penalties as well as the criminal law. ${ }^{104}$ It is also significant, in countering such concerns, that the 2008 Act does provide strong protection against regulator abuse ${ }^{105}$ and revenue collected through monetary penalties goes into a consolidated fund and is not available to the regulators. Proponents of civil penalties point to the fact that alternatives exist therein for less heavy-handed and more costeffective enforcement as well as the capacity to respond quickly to emergency situations and the technical expertise, with the regulatory body, which will enable a more proportionate response. ${ }^{106}$ To date the only civil sanctions activity has been in the acceptance of enforcement undertakings and this has been almost exclusively in the area of waste regulation, particularly waste packaging offences. ${ }^{107}$ It is, thus, too early to judge the success or impact of the new powers. However, it should be remembered that the intention was that civil sanctions should be an additional tool, and not a substitute for criminal prosecution.

\section{New sentencing powers}

It is all too often overlooked in the discussion of the introduction of civil sanctions, that the recommendations of Macrory on the implementation of administrative alternatives to prosecution were accompanied with

99 Oliver Letwin as reported in ENDS Report, 7 April 2011, available at $h t t p: / / w w w$. endsreport.com/27656, accessed 18 April 2013.

100 See, e.g., Black, above n. 97; Maurici, above n. 98.

101 Ibid.

102 For example, enforcement notices and fixed penalties for littering.

103 For example, financial services and utilities; R. Macrory, 'Rethinking Regulatory Sanctions-Regulatory Enforcement and Sanctions Act 2008-An Exchange of Letters' (2009) 21 Environmental Law and Management 183.

104 For example, Australia, Canada and the United States; Macrory, above n. 102.

105 The requirement for the regulator to be satisfied beyond reasonable doubt that an offence has been committed in s. 39(2) and s. 42(2). The serving of notices and the opportunity for representations and the right of appeal to the independent First-tier tribunal (s. 40(6) and s. 43(7)).

106 C. Abbot, 'The Regulatory Enforcement and Sanctions Act 2008' (2009) 11 Environmental Law Review 38.

107 All for offences under the Producer Responsibility Obligations (Packaging Waste) Regulations 2007 (SI 2007 No. 871). 
proposals for the strengthening and extension of the range of sentencing powers available to the courts. Macrory recommended the introduction of profits orders, corporate rehabilitation orders, publicity orders and community project orders in addition to the sentencing powers already available to the courts for environmental offences. ${ }^{108}$ The DEFRA Better Environmental Enforcement Project that consulted on the introduction of civil sanctions under the 2008 Act, as well as concluding that civil sanctions would help create 'a better graduated system of enforcement', also contained outline proposals to strengthen sentencing powers for those very serious cases which would still come to be prosecuted. DEFRA states that the government is looking to introduce new powers 'to assist the courts in structured proportionate and effective sentencing of the especially serious environmental offences . . . ${ }^{109}$

Publicity and profit orders as well as environmental service orders, environmental audit orders and corporate rehabilitation orders are all under consideration.

\section{Conclusions and recommendations}

As noted above the recently introduced civil sanctions are, at the moment, very limited in their availability. Also, they do not replace lowlevel criminal offences, but merely offer alternatives to criminal prosecution. Strict liability environmental offences can still be prosecuted in the courts and the relaxed approach to the requirement for legal causation for the moment remains in place for environmental crime. The introduction of civil sanctions may well lead to more effective enforcement by the regulator without the need to bring some incidents to the magistrates' courts, although this waits to be seen. Cases of a more serious nature will continue to be heard in the magistrates' courts and higher courts and the likelihood remains of low level and, arguably, inappropriate sentences.

The introduction of new sentencing powers would assist in allowing magistrates to sentence appropriately and proportionally and serve to provide more effective deterrents to those who engage in environmental crime. It is also vital that sentencing guidelines are available to the lower courts as they are with other areas of criminal activity. The Environment Agency's view is that the lack of specific criteria for sentencing is one of the major reasons for disparity in sentencing across magistrates' courts $^{110}$ and early action by the Sentencing Council in publishing guidelines for environmental offences would be widely welcomed.

However, the complexity of environmental prosecutions remains and the inexperience of lay magistrates together with a low level of training may well continue to present problems with enforcement in the magistrates' courts. Perhaps, fresh attention should be given to the possibility of either a number of specialist magistrates' courts across the country or

108 Macrory, above n. 71.

109 Fairer and Better Environmental Enforcement-Government Response to Consultation, DEFRA, February 2010.

110 Stott, above n. 66. 
specially trained district judges or lay magistrates to constitute the bench for environmental offences. If powers of sentencing are widened, then there is yet more argument for experienced and adequately trained legal personnel to be able to administer appropriate and proportionate deterrent sentences. Resources for training magistrates are limited, and this proposal would have the benefit of targeting these scarce resources to best effect. There is a proven model in operation for health and safety offences, which could be successfully emulated for dealing with environmental crime.

The serious nature of environmental crime, acknowledged by many and reflected in the high level of upper limit penalties in the courts, does not sit comfortably with the strict liability of most environmental offences. One of the main justifications for the imposition of strict liability is that it is suited to low-level, less blameworthy offences which carry little stigma. Indeed, there are those that draw the line for strict liability at the point where offences attract a potential penalty of imprisonment. ${ }^{111}$ Arguably, environmental offences nowadays are not only viewed as serious, but the stigma that they attract, even for companies, is much greater than in the past. This is a serious matter for the reputation of corporate entities, which can be severely damaged by an environmental incident and attendant publicity and which can bear significant financial consequences. ${ }^{112}$

Some of the consultation responses to Professor Macrory's 2006 review supported the prospect of decriminalising certain regulatory offences entirely and reserving criminal sanctions for only the most serious cases of regulatory non-compliance. ${ }^{13}$ The Macrory review did not consider the status of current offences and this area was taken up more recently in a consultation by the Law Commission. ${ }^{114}$ The Law Commission proposed that low-level regulatory offences should be repealed and only those offences serious enough to attract either a prison sentence or an unlimited fine should be regarded as serious enough to warrant criminalisation. They further proposed that low-level offences are replaced by the introduction of a civil penalty or equivalent measure. ${ }^{115}$ With those criminal offences that remain, the Law Commission suggested that the fault element ${ }^{116}$ should be proportionate to the risk of harm, with higher level fault requirements where the risk of harm is remote. ${ }^{117}$ There is a clear movement here away from the current, strict liability, status of most environmental offences. Furthermore, the Law Commission proposed a power for the courts to apply a due diligence defence to any statutory offence that does not require proof of fault. ${ }^{118}$

111 Baker, above n. 15 at 1280; Simester et al., above n. 1 at 175 .

112 For example, BP with the recent Gulf of Mexico oil pollution incident.

113 Macrory, above n. 71 at para. 1.39.

114 Law Commission, Law Com. Consultation Paper No. 195, Criminal Liability in Regulatory Contexts (2010).

115 Ibid. at 8.

116 Such as dishonesty, intention, knowledge or recklessness.

117 Law Commission, above n. 114 at 13.

118 Ibid. at 15. 
The UK Environmental Law Association (UKELA), in response to the Law Commission consultation, ${ }^{119}$ did not favour the decriminalisation of low-level environmental offences. It pointed to the fact that existing offences do not naturally fall into serious or non-serious categories and it preferred civil sanctions as an alternative rather than a replacement. Simester also recognised the difficulty of drawing the line between those offences which carry stigma and those that do not in his consideration of restricting strict liability to stigmatic crimes. ${ }^{120}$ UKELA further pointed out that decriminalisation may fall foul of the Environmental Crime Directive, ${ }^{121}$ which requires certain environmental activities to be subject to criminal offences. In respect of the recommendation for a general defence of due diligence, they consider that further evidence and debate is necessary before such a defence be introduced for all environmental offences.

In the light of the introduction of civil sanctions and changing perceptions of environmental crime, it is perhaps time to open up the debate with regards to the nature of environmental offences. The introduction of more fault-based offences and a general due diligence defence could go towards reinforcing the seriousness of environmental crime and ensuring that perpetrators are appropriately and proportionally punished. It may also be the case, that the higher courts, when next faced with a case such as Empress may (particularly in the light of Kennedy No. 2) take a more traditional approach to legal causation, thus bringing pollution offences into line.

The view that environmental crime is not 'real crime' is grounded in the belief that it does not generally result in direct harm to the individual or threaten social stability. ${ }^{122}$ This may well be the case, but environmental law seeks to address an even greater challenge, to the survival of society itself. As Hatton et al. point out:

Environmental law carries a responsibility to ensure justice not only for the individual citizen, but for the collective benefit of our environment-both now and for future generations. ${ }^{123}$

If the courts do not respond with appropriate and substantial penalties for the most serious incidents, then the view that environmental wrongs are not worthy of society's condemnation will prevail and justice will not be done to the environment or society.

119 UKELA, UKELA's Response to Law Commission Consultation Paper No. 195: Criminal Liability in Regulatory Contexts, November 2010, available at http://www.ukela.org/ content/doclib/193.pdf, accessed 18 April 2013.

120 Simester, above n. 17.

121 Directive 2008/99/EC on the protection of the environment through criminal law (OJ No. L328128, 6 December 2008).

122 Hatton et al., above n. 58.

123 Ibid. 